\title{
Centroblastic Lymphoma by Ann Arbor Stage
}

National Cancer Institute

\section{Source}

National Cancer Institute. Centroblastic Lymphoma by Ann Arbor Stage. NCI Thesaurus.

Code C141263.

An anatomic stage for centroblastic lymphoma based on the Ann Arbor classification criteria. 